\title{
TRANSFER OF CELLULOLYTIC CHARACTER OF ASPERGILLUS NIGER INTO ASPERGILLUS KAWACHII BY THEIR PROTOPLAST FUSION
}

\author{
KIHACHIRO OGAWA,* NOBORU FUJII, KATSUMI FURUKAWA, \\ REKI W. ASHADI, PRANEE THAYANANUPHAT, \\ AND KIYOHARU TANAKA ${ }^{1}$ \\ Department of Biological Resource Sciences, Faculty of Agriculture, Miyazaki University, \\ Miyazaki 889-21, Japan \\ ${ }^{1}$ Oita Prefectural Usa Agriculture Senior High School, Usa 879-04, Japan
}

(Received January 11, 1993)

The feasibility of obtaining useful interspecific hybrids with high cellulolytic activities by breeding was investigated by a protoplast fusion technique using the citric acid hyper-producer, Aspergillus kawachii, and the cellulase hyper-producer, Aspergillus niger. Interspecific hybridization between two auxotrophic mutants of Aspergillus kawachii (his) and $A$. niger (met) was achieved by protoplast fusion in the presence of 35\% polyethylene glycol as fusogen. Stable diploid strains were obtained from a heterokaryon strain by treatment with $0.1 \% d$-camphor. The selected strains were specified by their conidial size and DNA content as well as the conidial germination. One of them showed high cellulase productivity besides the same level of amylase production and sporulation as that of $\boldsymbol{A}$. kawachii, a higher level of citric acid and the lowering of mash viscosity than that of $A$. kawachii. From these results it is suggested that this diploid strain would be very useful for the degradation of cellulosic substances in the mash from shochu fermentation, consequently for its ready disposal thereafter.

Distillery waste from shochu fermentation mash has recently become a social problem as a source of pollution. One of the useful tools for resolution of this problem seems to be the transference of a character to produce cellulase and its related enzymes into the non-cellulolytic fungus, Aspergillus kawachii Kitahara, which is the major microbe proliferating in the mash. The potential candidate may be a highly cellulase-producing fungus, Aspergillus niger. The cellulosic substances

* Address reprint requests to: Dr. Kihachiro Ogawa, Department of Biological Resource Sciences, Faculty of Agriculture, Miyazaki University, 1-1 Gakuen-kihanadai-nishi, Miyazaki 889-21, Japan. 
therein will be degraded through the treatment to result in lowering the viscosity of the whole mash and they may become easily disposable thereafter. Thus, for example the solid-liquid separation of the fermentation mash, concentration of supernatant, and foraging and composting of the solid-residue may be readily realized. Only a few studies have been made so far for this kind of study by a protoplast fusion procedure. In this work, the feasibility of breeding to obtain useful interspecific hybrids having a high cellulase activity was pursued by the method of protoplast fusion using the citric acid hyper-producer, A. kawachii, and the cellulase hyper-producer, $A$. niger.

\section{MATERIALS AND METHODS}

Organisms. The citric acid hyper-producer, Aspergillus kawachii Kitahara KGS (Kawachi Genichiro Shoten, Kagoshima, Japan) used for shochu fermentation, and a cellulase hyper-producer, Aspergillus niger UC (Ueda Chemical Industry Co., Ltd., Osaka, Japan), were employed as the original strains. Conidia of these strains were treated with UV rays in a routine manner. The auxotrophic single mutants obtained were checked for their stability over several vegetative generations, and for their characteristic amylase, cellulase and citric acid productions. Strain KK1 (his) is a mutant of $A$. kawachii Kitahara KGS and strain UC (met) is a mutant of $A$. niger UC. These parental strains also produced single nuclear conidia on a complete medium.

Mycolytic enzyme sources. Commercial enzyme preparation, Usukizyme (Kyowa Kasei Co., Ltd., Osaka, Japan), Trichoderma viride B1A preparation, chitinase (Sigma Chemical Co., St. Louis, U.S.A.) and hemicellulase (Ueda Chemical Ind. Co., Ltd.) were used in this work.

Cultivation of microorganisms. Czapek-Dox medium containing $2 \%$ glucose was used as a minimal medium (MM). The minimal medium supplemented with 0.5\% yeast extract (Difco Lab., Detroit, U.S.A.) and Casamino acid (Difco Lab.) was used as the complete medium (CM).

Preparation of protoplasts. Protoplast was prepared from mycelia by the method previously reported (8). About $200 \mathrm{mg}$ (wet weight) of mycelia was added to $5 \mathrm{ml}$ of a $3 \%$ Usukizyme solution [ $50 \mathrm{~mm}$ malate buffer, $\mathrm{pH} 5.6$, being added for $\mathrm{KK} 1$ (his)] or to a mixture of $8 \% T$. viride $\mathrm{B} 1 \mathrm{~A}$ preparation, $0.15 \%$ chitinase and $0.8 \%$ hemicellulase [ $50 \mathrm{~mm}$ malate buffer, $\mathrm{pH} 5.6$ being added for $\mathrm{UC1}$ (met)]. The individual mixtures were made to $0.6 \mathrm{M} \mathrm{KCl}$ or $\mathrm{NaCl}$ [for $\mathrm{KK} 1$ (his)] or $\mathrm{NaCl}$ for $\mathrm{UC1}$ (met) and they were incubated under shaking on Monod apparatus at $35^{\circ} \mathrm{C}$ for $1 \mathrm{~h}$. The reaction mixture was centrifuged at $700 \times g$ for $5 \mathrm{~min}$, and the protoplasts precipitated were suspended in a $1 \mathrm{ml}$ solution $(0.6 \mathrm{M} \mathrm{NaCl})$ which was osmotically balanced. The regeneration frequency was defined as the ratio of the number of colonies regenerating from the protoplasts and the total protoplasts used in the suspension. The real colonies regenerating from protoplasts were calculated by means of the water-lysis control test. 
Protoplast fusion. The methods of Annẽ and Peberdy (2) and the method reported previously $(9,10)$ were used under a slight modification. The fusion frequency was defined as the percentage ratio of the number of colonies developing on MM and CM agar after the fusion treatment.

Diploidization of heterokaryon. The same method as reported previously was used (8).

Determination of DNA. Conidia $\left(10^{9} / \mathrm{ml}\right)$ cultured at $25^{\circ} \mathrm{C}$ for 3 days were treated with $5 \mathrm{ml}$ of $0.25 \mathrm{~N} \mathrm{HClO}_{4}$ at $0^{\circ} \mathrm{C}$ for $30 \mathrm{~min}$ to eliminate low molecular weight substances in conidia. After elimination of the low molecular weight substances, nucleic acid was extracted with $4 \mathrm{ml}$ of $0.5 \mathrm{~N} \mathrm{HClO}_{4}$ at $70^{\circ} \mathrm{C}$ for $25 \mathrm{~min}$. The extraction was repeated 3 times. Determination of DNA was carried out in the same way as the method of Burton (3) after extraction by the method of Schneider (15). The DNA content per conidium was calculated as follows: $100 \times($ the amount of DNA in the conidia)/(the number of conidia tested) $\left(10^{-6} \mu \mathrm{g}\right)$.

Enzyme assays. Amylase activity was measured by the method reported previously $(9,10)$. The reducing sugar content was measured by the method using 3,5-dinitrosalicylic acid (16). Avicel saccharifying, CM-cellulose saccharifying, and $\beta$-1,3-glucanase activities were measured by the methods reported previously $(11,12)$. One unit of these enzyme activities was defined as an amount of enzyme which produced $1 \mu \mathrm{mol}$ of reducing sugar as glucose per min. Filter paper degrading activity was also assayed by the method reported previously (17).

Culture for enzyme preparation. Solid culture for amylase production was performed by the method previously reported (8). Citric acid was measured by the method of Kusunose (7). Solid and submerged cultures for cellulase production were performed by the following methods. In a $300 \mathrm{ml}$ Erlenmeyer flask, $10 \mathrm{~g}$ of wheat bran was mixed with tap-water at ratio of $1: 1$ for the solid culture. The flask was then autoclaved at $120^{\circ} \mathrm{C}$ for $20 \mathrm{~min}$, followed by an inoculation with small pieces of a solid seed culture. The flask was incubated at $30^{\circ} \mathrm{C}$ for 6 days. With the submerged culture of $T$. viride, $0.25 \mathrm{~g}$ of Avicel $\mathrm{PH}-101$ and $0.25 \mathrm{~g}$ of wheat germ were added to the medium in a $100 \mathrm{ml}$ Erlenmeyer flask (1). These flasks were autoclaved at $120^{\circ} \mathrm{C}$ for $20 \mathrm{~min}$, followed by an inoculation with small pieces of fungal mat grown on the slope. The flask was incubated with shaking on a rotary shaker (Iwashiya K, Sawada Co., Ltd., Tokyo, Japan) at $160 \mathrm{rpm} 25^{\circ} \mathrm{C}$ for 5 days.

Small-scale shochu mash. The small-scale shochu mashes consisting of $50 \mathrm{~g}$ of rice grain koji and $80 \mathrm{ml}$ of distilled water (for $1 \mathrm{st}$ mash), and $250 \mathrm{~g}$ of steamed sweet potato and $120 \mathrm{ml}$ of distilled water (for $2 \mathrm{nd}$ mash) were fermented at $25^{\circ} \mathrm{C}$ and $\mathrm{pH} 3.6$ for 5 days (for 1st mash), and $\mathrm{pH} 4.0$ for 8 days (for 2 nd mash).

Viscosity measurement of sweet potato shochu mash. Viscosity of a sweet potato shochu mash was measured using an electric rotary viscometer, Vismetron (Tokyo Keisoku Co., Ltd., Tokyo, Japan). 


\section{RESULTS}

\section{Protoplast fusion}

Protoplasts $\left(3.4 \times 10^{6} / \mathrm{ml}\right)$ of KK1 (his) were formed from mycelia by incubation with Trichoderma lytic enzyme preparation for $1 \mathrm{~h}$ in a hypertonic stabilizing solution with $0.6 \mathrm{M} \mathrm{KCl}$ or $\mathrm{NaCl}$. However, protoplasts from $\mathrm{UC1}$ (met) could not be formed from mycelia with only a single lytic enzyme system in using Trichoderma lytic enzyme preparation, but required a multilytic enzyme system for the protoplast $\left(3.0 \times 10^{6} / \mathrm{ml}\right)$ formation. Regeneration frequency of the KK1 (his) and UC1 (met) strains were 15.6 and 11.5\%, respectively. Protoplasts from KK1 (his) and UC1 (met) were fused using 35\% polyethylene glycol (m.w. 6,000) as reported previously $(8,9)$. After 5 days of incubation, fusants could be selected with nutritional complement as colonies appearing on $\mathrm{MM}$ agar after fusant treatment. The fusion frequency of the protoplasts was estimated to be $0.51 \%$, i.e., more than $10^{4}$ reversion rates of the fused auxotrophs (Table 1 ). The fusants that appeared on MM agar were transferred onto new MM slant. These fusants showed fine growth on MM agar and their conidia segregated into KK1 (his) and UC1 (met) of the parental auxotrophs showing segregation rates of $16: 84$ (Table 2). These results obviously verified that the fusants are heterokaryon.

Table 1. Fusion frequency between protoplasts of auxotrophic mutants.

\begin{tabular}{|c|c|c|c|c|c|}
\hline \multirow{2}{*}{$\begin{array}{l}\text { Protoplast } \\
\text { pair }\end{array}$} & \multirow{2}{*}{$\begin{array}{l}\text { Reversion rate } \\
\text { (less than) }\end{array}$} & \multicolumn{2}{|c|}{$\begin{array}{c}\text { Protoplast regenerated on } \\
\text { hypertonic CM }\end{array}$} & \multirow{2}{*}{$\begin{array}{l}\text { Fusant formed on } \\
\text { hypertonic MM }\end{array}$} & \multirow{2}{*}{$\begin{array}{l}\text { Fusion } \\
\text { frequency } \\
(\%)\end{array}$} \\
\hline & & $\begin{array}{l}\text { Before fusion } \\
\text { treatment }\end{array}$ & $\begin{array}{c}\text { After fusion } \\
\text { treatment }\end{array}$ & & \\
\hline $\begin{array}{l}\mathrm{KK} 1(\text { his })^{a} \\
\mathrm{UC1}(\text { met })^{b}\end{array}$ & $\begin{array}{l}2.9 \times 10^{-7} \\
2.2 \times 10^{-6}\end{array}$ & $\begin{array}{l}8.0 \times 10^{5} \\
6.5 \times 10^{5}\end{array}$ & $7.5 \times 10^{4}$ & $3.8 \times 10^{2}$ & 0.51 \\
\hline
\end{tabular}

Czapek-Dox medium containing $2 \%$ glucose was used for the minimal medium (MM). MM supplemented with $0.5 \%$ yeast extract and Casamino acid was used as complete medium (CM). Fusion was done by suspending the protoplasts in 35\% PEG (m.w. 6,000), $0.05 \mathrm{M} \mathrm{CaCl}, 0.05 \mathrm{M}$ glycine- $\mathrm{NaOH}$ buffer, $\mathrm{pH} 7.5\left(25^{\circ} \mathrm{C}\right.$ for $\left.15 \mathrm{~min}\right)$. After being washed with $0.6 \mathrm{M} \mathrm{NaCl}$, a series of appropriately diluted protoplast suspensions were plated onto hypertonic MM and CM agar.

a KK1 (his): An auxotrophic mutant from A. kawachii Kitahara KGS.

${ }^{b} \mathrm{UC1}$ (met): An auxotrophic mutant from $A$. niger UC.

Table 2. Segregation of heterokaryons after fusion.

\begin{tabular}{cc}
\hline Protoplast pair & Segregation (\%) \\
\hline KK1 (his) & 16 \\
$\mathrm{UC1}(\text { met })^{b}$ & 84 \\
\hline
\end{tabular}

Appearance frequency of diploids was represented by the ratio of the numbers of conidia regenerating on $\mathrm{CM}$ and $\mathrm{MM}$ agars.

${ }^{a}$ KK1 (his): An auxotrophic mutant from A. kawachii Kitahara KGS

${ }^{b} \mathrm{UC1}$ (met): An auxotrophic mutant from $A$. niger UC. 


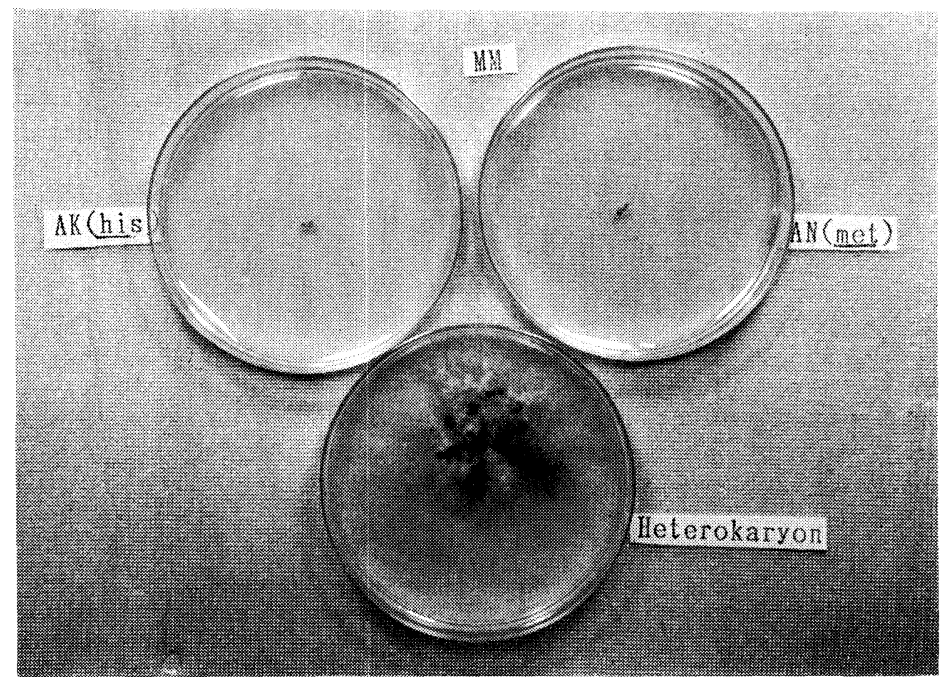

Fig. 1. Conformation of heterokaryon by growth on minimal medium.

Czapek-Dox medium agar was used for as a minimal medium. The photograph was taken after 6 days of incubation at $25^{\circ} \mathrm{C}$. AK (his): $\mathrm{KK} 1$ (his); $\mathrm{AN}$ (met): UC1 (met).

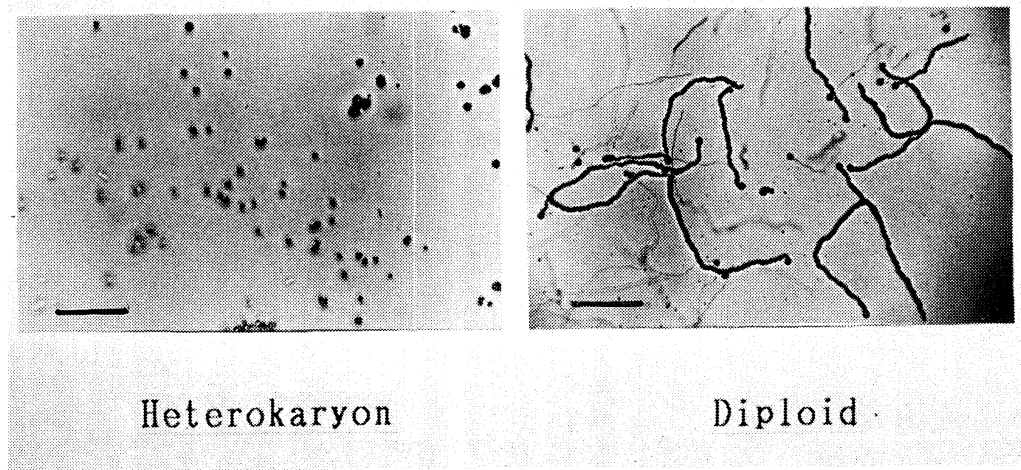

Fig. 2. Germination of diploid conidia on minimal medium.

The photograph was taken after $20 \mathrm{~h}$ of incubation at $25^{\circ} \mathrm{C}$. The bar marker represents $45 \mu \mathrm{m}$.

\section{Preparation of heterozygous diploid'}

A loopful of mycelia mixed with conidia from a heterokaryon strain, H-KK1$\mathrm{UC1}$, was inoculated onto a Petri dish of MM agar containing $0.1 \% d$-camphor (14), followed by incubation at $30^{\circ} \mathrm{C}$ for 5 days. The mycelia showed nice growth and sporulation, some sectors evidently being produced. The conidia heads in the sectors were either black or brown (Fig. 1). Heterozygous diploids could be selected on the basis of germinated conidia on MM agar, as shown in Fig. 2. The 
Table 3. DNA content of conidia of haploids and diploids.

\begin{tabular}{lcc}
\hline & \multicolumn{2}{c}{ DNA } \\
\cline { 2 - 3 } Strain & $10^{-8} \mu \mathrm{g}$ per conidium & $10^{-8} \mu$ g per nucleus \\
\hline A. kawachii Kitahara & 13.41 & 13.41 \\
A. niger UC & 12.76 & 12.76 \\
KK1 $(\text { his })^{a}$ & 12.13 & 12.13 \\
UC1 $(\text { met })^{b}$ & 12.58 & 12.58 \\
Heterokaryon (H-KK1-UC1) & 12.00 & 12.00 \\
Diploid (D-KK1-UC1) & 20.86 & 20.86 \\
\hline
\end{tabular}

DNA was measured by the method of Burton after extraction by the method of Schneider.

a KK1 (his): An auxotrophic mutant from A. kawachii Kitahara KGS.

${ }^{b} \mathrm{UCl}$ (met): An auxotrophic mutant from $A$. niger UC.

Table 4. Size of conidia of haploids and diploids.

\begin{tabular}{lcc}
\hline \multicolumn{1}{c}{ Strain } & Diameter $^{c}$ & (Ave. $\mu \mathrm{m})$ \\
\hline KK1 $(\text { his })^{a}$ & $2.4-4.8$ & $(4.6)$ \\
UC1 $(\text { met })^{b}$ & $2.3-4.5$ & $(4.3)$ \\
Heterokaryon (H-KK1-UC1) & $2.5-4.8$ & $(4.5)$ \\
Diploid (D-KK1-UC1) & $4.5-7.1$ & $(5.3)$ \\
\hline
\end{tabular}

${ }^{a}$ KK1 (his): An auxotrophic mutant from $A$. kawachii Kitahara KGS.

${ }^{b} \mathrm{UC1}$ (met): An auxotrophic mutant from $A$. niger UC.

c The measurement was done on at least 200 conidia of each strain and the ranges of conidial diameters are shown.

Table 5. Properties of heterokaryon and diploid.

\begin{tabular}{lccc}
\hline \multicolumn{1}{c}{ Strain } & $\mathrm{pH}$ & $\begin{array}{c}\text { Citric acid } \\
(\mathrm{mg} / 1 \mathrm{~g} \text { of wet } k \text { oji })\end{array}$ & $\begin{array}{c}\text { Amylase } \\
(\text { units/ml })\end{array}$ \\
\hline A. kawachii Kitahara & 4.78 & 7.66 & 157.5 \\
A. niger UC & 4.92 & 7.44 & 218.3 \\
KK1 (his) & & 5.13 & 59.2 \\
$\mathrm{UC1}\left(\right.$ met $^{b}$ & 5.35 & 7.92 & 192.4 \\
Heterokaryon (H-KK1-UC1) & 4.17 & 7.50 & 168.2 \\
Diploid (D-KK1-UC1) & 4.62 & 8.01 & 185.0 \\
\hline
\end{tabular}

The koji extract was prepared by extraction of the solid culture with one volume (for a fresh culture) of distilled water at room temperature for $1 \mathrm{~h}$.

a KK1 (his): An auxotrophic mutant from A. kawachii Kitahara KGS.

${ }^{b} \mathrm{UC1}$ (met): An auxotrophic mutant from A. niger UC.

frequency of diploidization was $5.6 \times 10^{3}$. A diploid strain, D-KK1-UC1, showed 1.6-fold DNA content per nucleus (Table 3 ). The conidia diameter of this diploid strain was much greater than those of the original strains (Table 4). Nuclear number of the diploid conidia was verified to be single nucleus by DAPI staining methods (5). Citric acid and amylase productivities of a diploid strain, D-KK1UC1. 
Table 6. Cellulase activity (filter paper degrading activity) of heterokaryon and diploids.

\begin{tabular}{|c|c|c|}
\hline \multirow{2}{*}{ Strain } & Solid culture & Submerged culture \\
\hline & FPD activity $^{c}$ (units/mg) & 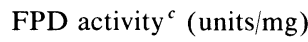 \\
\hline A. kawachii Kitahara & 250 & 200 \\
\hline A. niger UC & 1,000 & 500 \\
\hline $\mathrm{KK} 1{\text { (his })^{a}}^{-}$ & 200 & 188 \\
\hline $\mathrm{UC} 1(m e t)^{b}$ & 600 & 500 \\
\hline Heterokaryon (H-KK1-UC1) & 429 & 333 \\
\hline Diploid (D-KK1-UC1) & 1,500 & 600 \\
\hline
\end{tabular}

a KK1 (his): An auxotrophic mutant from A. kawachii Kitahara KGS.

${ }^{b} \mathrm{UCl}$ (met): An auxotrophic mutant from $A$. niger UC.

c Filter paper degrading activity.

Table 7. Cellulase activities of heterokaryon and diploid.

\begin{tabular}{|c|c|c|c|}
\hline Strain & $\begin{array}{c}\text { Avicel saccharifying } \\
\text { activity } \\
\text { (units } / \mathrm{ml} \text { ) }\end{array}$ & $\begin{array}{c}\text { CM-cellulose } \\
\text { saccharifying activity } \\
\text { (units } / \mathrm{ml})\end{array}$ & $\begin{array}{c}\beta-1,3-\text { Glucanase } \\
\text { activity } \\
\text { (units } / \mathrm{ml} \text { ) }\end{array}$ \\
\hline A. kawachii Kitahara & 1.2 & 0.2 & 1.4 \\
\hline A. niger UC & 6.4 & 1.5 & 4.4 \\
\hline $\mathrm{KK} 1(\text { his })^{a}$ & 0.5 & 0 & 0.4 \\
\hline $\mathrm{UCl}(\text { met })^{b}$ & 5.3 & 1.0 & 3.5 \\
\hline Heterokaryon (H-KK1-UC1) & 4.4 & 0.3 & 2.6 \\
\hline Diploid (D-KK1-UC1) & 6.5 & 0.5 & 4.8 \\
\hline
\end{tabular}

Enzyme solution was obtained by submerged culture.

${ }^{a}$ KK1 (his): An auxotrophic mutant from A. kawachii Kitahara KGS.

$b$ UC1 (met): An auxotrophic mutant from $A$. niger UC.

The diploid strain was assayed for the citric acid and amylase productivities. The citric acid and amylase productivities levels in the diploid strain cultured on solid rice grain were enhanced as compared with those of original strain, $A$. kawachii Kitahara KGS (Table 5). This strain produced phenotypically black conidia derived from $A$. niger UC.

\section{Cellulase activities of a diploid strain, D-KK1-UC1}

A diploid strain, D-KK1-UC1, showed 6-fold filter paper degradation for activity as compared with that of the original strain, A. kawachii Kitahara KGS, on solid and submerged culture (Table 6). Avicel and CM-cellulose saccharifying and $\beta$-1,3-glucanase activities of D-KK1-UC1 also showed higher (i.e., 6.3- and 2.5fold) activities than those of $A$. kawachii Kitahara KGS, respectively (Table 7). These results confirmed that cellulase producing character originated in $A$. niger UC has been transferred into $A$. kawachii Kitahara by the protoplast fusion technique. 
Table 8. Lowering the viscosity of shochu mash using a cellulase-inducible fusant.

\begin{tabular}{|c|c|c|c|}
\hline Strain & Mash & $\begin{array}{l}\text { Ethanol concentration } \\
\text { in } 2 \text { nd mash }(\%)^{a}\end{array}$ & $\begin{array}{c}\text { Final mash } \\
\text { viscosity }(\mathrm{CPS})^{b}\end{array}$ \\
\hline \multicolumn{4}{|c|}{ A. kawachii Kitahara } \\
\hline & 1st mash & & 500 \\
\hline & Koji $50 \mathrm{~g}$ & & \\
\hline & Water $80 \mathrm{ml}$ & & \\
\hline & 2nd mash & 14.4 & \\
\hline & Sweet potato $250 \mathrm{~g}$ & & \\
\hline & Water $120 \mathrm{ml}$ & & \\
\hline \multicolumn{4}{|c|}{ Diploid (D-KK1-UC1) } \\
\hline & 1st mash & & 120 \\
\hline & Koji $50 \mathrm{~g}$ & & \\
\hline & Water $80 \mathrm{ml}$ & & \\
\hline & 2nd mash & 14.9 & \\
\hline & Sweet potato $250 \mathrm{~g}$ & & \\
\hline & Water $120 \mathrm{ml}$ & & \\
\hline
\end{tabular}

Two small-scale shochu mashes consisting of $50 \mathrm{~g}$ of rice grain koji and $80 \mathrm{ml}$ of distilled water (for $1 \mathrm{st}$ mash), and $250 \mathrm{~g}$ of steamed sweet potato and $120 \mathrm{ml}$ of distilled water (for $2 \mathrm{nd} \mathrm{mash}$ ), respectively were fermented at $25^{\circ} \mathrm{C}$ and $\mathrm{pH} 3.6$ for 5 days (for 1 st mash), and $\mathrm{pH} 4.0$ for 8 days (2nd mash).

${ }^{a}$ Ethanol concentration was assayed by the method of steam distillation.

b CPS: CGS unit of viscosity rate.

\section{Change of viscosity in sweet potato shochu mash}

Change of the viscosity in sweet potato shochu mash fermented with a fusant, D-KK1-UC1, was compared with that of $A$. kawachii Kitahara KGS. The viscosity of the shochu mash was lowered markedly (Table 8). Same result has been shown on shochu mash supplemented cellulase preparation (13).

Furthermore, the D-KK1-UC1 fusant grew well after sporulation under healthy condition on culture, and its productivities of citric acid and amylase, cellulase and related enzymes were found to be very stable even after 6 times successive transfers of culture.

\section{DISCUSSION}

A. kawachii Kitahara produces largely citric acid and acidic amylase, although the fungus is unable to produce cellulases and related enzymes such as hemicellulase. Therefore, transferring of the character cellulase and producing cellulase and related enzymes into this strain from some cellulolytic fungi is very useful for degradation of cellulosic substances in mash produced by fermentation industry. Since $A$. kawachii Kitahara is one of the fungi inhabiting the mash from shochu fermentation, we used $A$. niger UC as the donor of such character.

Preparation of mycelial protoplasts from $A$. kawachii Kitahara was first carried out using only lytic enzyme system of $T$. viride, but cooperation of multienzyme system including $\alpha$ - and $\beta$-glucanase, chitinase and hemicellulase beside $T$. viride 
lytic enzymes was necessary for this purpose in the case of $A$. niger UC. It was suggested that cell wall of this strain contained not only nigeran $(4,6)$ composed of $\alpha$-1,3- and 1,4-glucans but $\beta$-1,3-glucan and chitin.

The protoplast fusants obtained in this way were able to grow on MM agar, and conidia from fusants completely segregated into two types of parental auxotrophs. The result indicates that the protoplast fusants are heterokaryons. After heterokaryon H-KK1-UC1 was incubated on MM agar containing $0.1 \% d$ camphor, sectors developed and then germ tubes were developed from a part of the conidia in the sectors.

In this study, we selected a diploid strain D-KK1-UC1 from above sectors. The diploidy of this strain was verified by germination and growth on MM agar of the conidia, and by the diameter and DNA content of the conidia. The conidium from strain D-KK1-UC1, contained an about 1.6-fold amount of DNA and an about 1.3-fold conidial diameter compared with those of original strains. It seemed, therefore, reasonable to assume that strain D-KK1-UC1 is a heterozygous diploid. The diploid strain D-KK1-UC1 was regarded as a useful strain because of its high citric acid and amylase productivities in addition to cellulolytic activity. In the fermented mash of sweet potato including a large amount of parenchymatous cells and crude fibers, the lowering of mash viscosity was not shown by traditional process or by using amylase preparation only (13). When we used a fusant, DKK1-UC1 for making koji, the viscosity in the shochu mash lowered more markedly than that of $A$. kawachii Kitahara KGS. It can therefore be presumed that lowering of the viscosity in the shochu mash is caused by degradation of sweet potato cell walls. By lowering of the viscosity in the shochu mash, the solid-liquid separation of the fermentation mash, elevation of fermentation efficiency (13), and foraging and composting of the solid-residue may be realized. From these results it seems apparent that protoplast fusion technique will practically be a useful tool for transferring the character for the producibility of cellulase and related enzymes from a highly cellulase-producing fungus into a non-celluloytic one.

\section{REFERENCES}

1) Andreotti, R. E., Mandels, M., and Roche., Cellulase production of Trichoderma in solid and submerged cultured methods. Proc. Biocon. Symp., IIT, 305-327 (1977).

2) Annẽ, J. and Peberdy, J. F., Induced fusion of protoplasts following treatment polyethylene glycol. J. Gen. Microbiol., 92, 413-417 (1976).

3) Burton, K., A study of the conditions and mechanism of the diphenylamine reaction for the colorimetric estimation of deoxyribonucleic acid. Biochem. J., 62, 315-325 (1956).

4) Gold, H. M., Mitzel, D. L., and Segel, I. H., Regulation of Nigeran accumulation by Aspergillus aculeatus. J. Bacteriol., 113, 856-862 (1973).

5) Iwase, K., Matsui, S., Taniguchi, T., and Obayashi, A., Behavior of cell nuclei during basidiospore formation in Triocholoma matsutake. Trans. Mycol. Soc. Jpn., 28, 63-67 (1987).

6) Johonston, I. R., The composition of the cell wall of Aspergillus niger. Biochem. J., 96, 651-657 (1965).

7) Kusunose, M., Method of microdetermination of organic acid. III. Microassay of methabolic 
substances. Tanpakushitu Kakusan Koso, 2, 50-52 (1975).

8) Ogawa, K., Ohara, H., and Toyama, N., Intraspecific hybridization of Aspergillus awamori var. kawachi by protoplast fusion. Agric. Biol. Chem., 52, 337-342 (1988).

9) Ogawa, K., Ohara, H., and Toyama, N., Interspecific hybridization of Aspergillus awamori var. kawachi and Aspergillus oryzae by protoplast fusion. Agric. Biol. Chem., 52, 1985-1991 (1988).

10) Ogawa, K., Tsuchimochi, M., Taniguchi, K., and Nakatsu, S., Interspecific hybridization of Aspergillus usamii mut. shirousamii and Aspergillus niger by protoplast fusion. Agric. Biol. Chem., 53, 2873-2800 (1989).

11) Ogawa, K., Toyama, D., and Fujii, N., Microcrystalline cellulose-hydrolyzing cellulase (endocellulase) from Trichoderma reesei CDU-11. J. Gen. Appl. Microbiol., 37, 249-259 (1991).

12) Ogawa, K., Toyama, H., and Toyama, N., Native cellulose hydrolyzing Cellulase of Trichoderma reesei. J. Ferment. Technol., 60, 349-355 (1982).

13) Ogawa, K., Toyama, H., and Toyama, N., Utilization of enzyme preparation in shochu making. Bull. Fac. Agric. Miyazaki Univ., 29, 203-211 (1982).

14) Pontecorvo, G., Roper, J. A., and Forbes, J., Genetic recombination without sexual reproduction in Aspergillus niger. J. Gen. Microbiol., 8, 198-210 (1953).

15) Schneider, W. C., Phosphorous compounds in animal tissues III-A comparison of methods for the estimation of nucleic acid. J. Biol. Chem., 164, 747-751 (1946).

16) Sumner, J. B., A more specific reagent for the determination of sugar in urine. J. Biol. Chem., 65 , 393-395 (1925).

17) Toyama, N. and Ogawa, K., Sugar production from agricultural woody wastes by saccharification with Trichoderma viride cellulase. Biotechnol. Bioeng. Symp., 5, 225-244 (1975). 